\title{
Noribogaine Generalization to the Ibogaine Stimulus: Correlation with Noribogaine Concentration in Rat Brain
}

\author{
C. Zubaran, M.D., M. Shoaib, Ph.D., I.P. Stolerman, Ph.D., J. Pablo, M.S., and D.C. Mash, Ph.D.
}

The discriminative stimulus effects of ibogaine and noribogaine in rats have been examined in relation to their concentrations in blood plasma and brain regions and to receptor systems through which they have been proposed to act. Rats were trained to discriminate ibogaine $(10 \mathrm{mg} / \mathrm{kg}$ $I P)$, the NMDA antagonist dizocilpine $(0.08 \mathrm{mg} / \mathrm{kg} I P)$ or the $\kappa$-opioid agonist U50,488 (5 mg/kg IP) from vehicle in a standard two-lever operant conditioning procedure with a tandem VI-FR schedule of food reinforcement. Only rats trained on ibogaine generalized to noribogaine, which was approximately twice as potent as the parent compound. Noribogaine was detected in plasma and brain after administration of ibogaine and noribogaine. At the $E D_{50}$ doses for the discriminative effect, the estimated concentrations of noribogaine in plasma, cerebral cortex, and striatum were similar regardless of whether ibogaine or noribogaine was administered. The findings suggest that the metabolite noribogaine may be devoid of NMDA antagonist and $\kappa$-opioid agonist discriminative effects and that it may play a major role in mediating the discriminative stimulus effect of ibogaine.

[Neuropsychopharmacology 21:119-126, 1999] (C) 1999 American College of Neuropsychopharmacology. Published by Elsevier Science Inc.
KEY WORDS: Ibogaine; Noribogaine; Dizocilpine; $\kappa$-opioids; Drug discrimination; Rats

Ibogaine is a naturally occurring psychoactive alkaloid derived from the roots of the African shrub Tabernanthe iboga. Extracts of T. iboga are used for religious purposes in African cults. In the period from 1985 onward, several United States patents have claimed efficacy for ibogaine in the treatment of a wide variety of drugdependence syndromes (e.g., Lotsof 1985, 1992). These

From the Section of Behavioural Pharmacology (CZ, MS, IPS), Institute of Psychiatry, London, UK; Instituto de Biociências, (CZ), Universidade Federal do Rio Grande do Sul Brazil, Rio Grande, Brazil, SA; and the Department of Neurology (JP, DCM), University of Miami Medical School, Miami, Florida, USA.

Address correspondence to: Professor I.P. Stolerman, Section of Behavioural Pharmacology, Institute of Psychiatry, De Crespigny Park, London SE5 8AF, England. Tel: +44-171-919-3370; Fax: +44171-740-5305.

Received September 16, 1998; revised December 2, 1998; accepted January 4, 1998 . claims have attracted the attention of scientists, and there have been more than 60 scientific publications addressing several issues related to ibogaine and drug dependence.

Animal studies and uncontrolled observations in humans indicate that ibogaine can reduce withdrawal symptoms and self-administration of some drugs (Cappendijk and Dzoljic 1993; Sheppard 1994). Interestingly, in certain behavioral and neurochemical investigations, ibogaine has been characterized to have long-term effects persisting for at least 19 hours after its administration (Maisonneuve et al. 1991). In individuals given 5 $\mathrm{mg}$ of ibogaine, this drug could not be detected after 4 hours using thin-layer chromatography (Ley et al. 1996). Because the presence of ibogaine in plasma cannot explain its protracted actions, the possibility that an ibogaine metabolite persists for a longer period than the parent compound has been considered. Using quantitative gas chromatography/mass spectrometry, it was possible to detect the ibogaine metabolite 12-hydroxyi- 
bogamine (noribogaine) in plasma (Mash et al. 1995a); while more than $90 \%$ of the ibogaine absorbed was eliminated 24 hours after its administration, the concentration of the metabolite was still appreciable at this time. Ligand-binding studies suggest that noribogaine, like ibogaine itself, may interact with diverse types of receptor (Mash et al. 1995a; Staley et al. 1996). The primary metabolite noribogaine is produced through demethylation of ibogaine (Mash et al. 1995a). Ibogaine is lipophilic and concentrated in fat, and might be converted to noribogaine after slow release from fat tissue (Hough et al. 1996). Sequestration of ibogaine into lipophilic compartments in the brain may result in low drug concentrations in the extracellular fluid and the more polar nature of noribogaine suggests that it may achieve relatively higher concentrations than the parent compound (Staley et al. 1996).

Schechter and Gordon (1993) showed that rats can be trained to discriminate the interoceptive stimuli produced by ibogaine using drug discrimination procedures similar to those employed for many other drugs. In such studies, ibogaine has been found to partially cross-generalize with several drugs acting directly or indirectly as serotonergic agonists. Thus ibogaine generalized partially to fenfluramine, 1-(m-trifluoromethylphenyl)piperazine (TFMPP), lysergic acid diethylamide (LSD), 2,5-dimethoxy-4-methyl-amphetamine (DOM), and quipazine (Schechter and Gordon 1993; Helsley et al. 1998a). Conversely, in rats trained to discriminate fenfluramine, there was no generalization to ibogaine (Schechter 1997) whereas in rats trained on LSD or DOM, partial generalization was seen (Palumbo and Winter 1992).

In rats trained to discriminate ibogaine, partial generalizations to drugs of other classes have been observed. These drug classes include certain opioids and sigma agonists and $N$-methyl-D-aspartate (NMDA) antagonists. Thus, several mixed agonist-antagonist opioids, such as ( \pm )-pentazocine, nalorphine and diprenorphine, and sigma agonists such as 1,3-di(2-tolyl)guanidine have elicited partial generalization in rats (Helsley et al. 1998b). On the other hand, the selective к-opioid agonists U50,488 and bremazocine and subtype-selective sigma agonists have not generalized (Helsley et al. 1998b). Mice trained in a T-maze to discriminate the uncompetitive NMDA antagonist dizocilpine (but not the glycine antagonist $R-(+)-3$-amino-1-hydroxypyrrolid-2one) have also been reported to generalize to ibogaine (Popik et al. 1995; Witkin et al. 1995); however, the effect in dizocilpine-trained mice was only partial $(67 \%)$ and it occurred with a very large $(100 \mathrm{mg} / \mathrm{kg})$ dose of ibogaine. It has also been found that uncompetitive NMDA antagonists such as phencyclidine and dizocilpine do not cross-generalize with ibogaine in either rats or monkeys (Helsley et al. 1998b; Jones et al. 1998).

The studies reviewed above indicate that ibogaine has complex and incompletely characterized effects in drug discrimination experiments. Ibogaine and noribogaine appear to interact with several molecular targets (Deecher et al. 1992; Mash et al. 1995a, 1995b; Staley et al. 1996) but although their chemical structures are similar, the parent compound and its metabolite display different pharmacological and binding profiles. Noribogaine is several times less potent than the parent compound as an inhibitor of $\left[{ }^{3} \mathrm{H}\right]$ dizocilpine binding (Mash et al. 1995b), but it is more potent than ibogaine at both $\mu$ - and $\kappa$-opioid receptors and, unlike ibogaine, it is potent at the $\delta$-opioid receptor (Pearl et al. 1995). Additionally, noribogaine binds to the serotonin transporter with 10 -fold greater affinity than ibogaine and competitively inhibits $\left[{ }^{3} \mathrm{H}\right]$ dizocilpine and $\left[{ }^{3} \mathrm{H}\right] \mathrm{TCP}$ (1-[1-(2-thienyl)-cyclohexyl]piperidine) binding to ion channels of NMDA receptors (Mash et al. 1995a; Popik et al. 1994; Sweetnam et al. 1995).

Evidence suggests that the effects of the metabolite noribogaine may be an important element in the stimulus properties of ibogaine. Rats trained to discriminate ibogaine partially generalized to noribogaine (Helsley et al. 1997). In this study, we have attempted to determine the role of the metabolite noribogaine in the discriminative stimulus effect of ibogaine. Thus we examined the relationship between tissue concentrations of ibogaine and noribogaine and the behavioral response in rats of the same sex, strain, and age. We have also investigated whether rats trained to discriminate either the $\mathrm{\kappa}$-opioid agonist U50,488 or the uncompetitive NMDA antagonist dizocilpine will generalize to noribogaine.

\section{MATERIALS AND METHODS}

\section{Animals}

Male hooded rats (Harlan Olac, Bicester) initially weighing 210-280 g were housed individually in rooms maintained at $\sim 21^{\circ} \mathrm{C}$, with a regular light-dark cycle (light from 7:30 A.M. to 7:30 P.M.). The rats were fed restricted amounts of food to maintain their weights at $\sim 80 \%$ of normal, as determined from growth curves for rats with unrestricted access to food. The final weights of animals in the experiment were $300-360 \mathrm{~g}$. Water was available in the living cages at all times.

\section{Apparatus}

Standard experimental chambers (Campden Instruments) were contained in sound-insulated, ventilated enclosures. The chambers were fitted with two retractable levers separated by a recess into which $45 \mathrm{mg}$ pellets of food could be delivered. White noise was present at all times to mask external sounds. The Arachnid software system running under RISC OS was used to control the experiments and to record data (CeNes Ltd., Cambridge, UK). 


\section{Drug Discrimination}

The procedure for establishing drug discrimination has been described in detail (Pratt et al. 1983; Stolerman et al. 1984). Three groups of rats were used $(n=5-6)$. One group of rats was trained on ibogaine $(10 \mathrm{mg} / \mathrm{kg} \mathrm{IP})$, another group was trained on dizocilpine $(0.08 \mathrm{mg} / \mathrm{kg}$ IP), and a third group was trained on U50,488 (5 mg/ $\mathrm{kg}$ $\mathrm{SC})$. The training doses were chosen from previous work and preliminary experiments (Chamberlain and Stolerman 1997; Helsley et al. 1997; Sanger and Zivkovic 1989). Preliminary training was attempted with a $20-\mathrm{mg} / \mathrm{kg}$ dose of ibogaine but this induced severe behavioral disruption and was discontinued. In order to establish a baseline of responding in the absence of drug, rats were trained in 15-minute daily sessions to press levers for food reinforcers delivered on a FR-10 schedule, but only one lever was present at a time. Drug discrimination training then began, with both levers present at all times. During the training sessions of 15 minutes duration, presses on one of the two levers were reinforced after administration of the training drug; presses on the other lever were reinforced in sessions after saline injections. Drug and saline training sessions took place in random order. For all rats, a tandem VI 1-minute FR-10 schedule was introduced progressively. Under this schedule, food was presented following the tenth consecutive correct response after a randomly determined interval (mean $=1$ minute).

Test sessions for determining discriminative stimulus effects of drugs consisted of 5-minute generalization tests that took place twice weekly under extinction conditions; training continued on the intervening days. Rats used in these studies reached a criterion of at least $80 \%$ correct responding during extinction tests in the presence of training stimuli (after 35-55 training sessions for dizocilpine, 40-70 sessions for ibogaine and U50,488). Every subsequent experiment included tests with the drug and vehicle training stimuli as part of the random sequence of tests used to evaluate effects of novel drugs and doses. Subjects were used for tests of generalization to other drugs between acquisition and collection of the data described here; some of these other experiments have been described elsewhere (Chamberlain and Stolerman 1997).

The index for assessing discriminative effects was the number of responses on the lever appropriate for the training drug, calculated as a percentage of the total number of responses on both levers. This index was calculated for rats that pressed the levers at least 10 times during a 5-minute extinction test. $\mathrm{ED}_{50}$ values for discriminative effects were estimated by interpolation as the doses or tissue concentrations of drug associated with 50\% drug-appropriate responding. Data were examined by analysis of variance, with repeated measure techniques used where appropriate (Winer 1970). Per- centage data were subjected to arc-sine transformation. The Dunnett $t$-test was used for multiple comparisons with vehicle control data. The total number of responses was used as an index of response rate. All analyses were performed using Unistat 4.5 software (Unistat, London, UK).

\section{Ibogaine and Noribogaine Concentrations}

Rats were decapitated and trunk blood was collected. The blood was centrifuged and the plasma was retained for determination of drug concentrations. The brain was removed and various regions were dissected. Samples were extracted and analyzed as published previously (Hearn et al. 1995). A 400- $\mu$ l volume of each sample was added to a $15-\mathrm{ml}$, silanized, round-bottom, screw-top glass tube. Stock plasma $(400 \mu l)$ was used to prepare standards. Plasma samples and standards were diluted with $2.6 \mathrm{ml}$ of $1 \%$ sodium chloride and then made basic with $2 \mathrm{ml}$ saturated sodium carbonate. Dissected brain regions (brainstem, cerebellum, cortex, and striatum) from individual animals were minced and placed into individual tubes. Standard brain matrix (0.15 g/tube) was made from homogenized whole rat brain resulting in a homogenous paste. Brain samples were processed by 1:1 dilution $(\mathrm{w} / \mathrm{w})$ with $1 \%$ sodium chloride and then liquefied by homogenization for 30 seconds (Tissue Tearor ${ }^{\mathrm{TM}}$; Biospec Products, Bartlesville, $\mathrm{OK}$ ) and sonication for 5 minutes (Sonicator ${ }^{\mathrm{TM}}$; Heat Systems-Ultrasonics, Danbury, CT). Tubes containing brain homogenates were diluted with saturated sodium chloride solution ( $3 \mathrm{ml} / \mathrm{g}$ wet weight of tissue), and then made basic with saturated sodium carbonate ( $3 \mathrm{ml} / \mathrm{g}$ wet weight of tissue). Ibogaine- $\mathrm{d}_{3} /$ noribogaine$\mathrm{d}_{2}$ (100 ng) was added to all samples and standards as internal standard (istd).

Samples and standards of either plasma or brain were then extracted with $7 \mathrm{ml}$ ethyl acetate followed by rotation for 1 hour at room temperature. After centrifugation, the ethyl acetate layer was transferred to a second tube and evaporated to dryness at $50^{\circ} \mathrm{C}$ under a continuous stream of nitrogen. Noribogaine was derivatized by adding $100 \mu l$ tetramethyl analinium methoxide-dimethylsulfoxide (1:1) reagent and $40 \mu$ liodoethane, and incubating for 30 minutes at room temperature and for 5 minutes at $45^{\circ} \mathrm{C}$. The reaction was terminated by adding $2 \mathrm{ml} 2 \mathrm{~N}$ sulphuric acid. The resulting aqueous solution was then washed once with $5 \mathrm{ml}$ hexane and once with $5 \mathrm{ml} n$-butyl chloride for 30 minutes using a rotary mixer. After centrifugation, the organic layer was aspirated to waste. The aqueous phase was adjusted to a pH greater than 10 by adding $450 \mu 110 \mathrm{M}$ sodium hydroxide and $1 \mathrm{ml}$ saturated sodium carbonate and extracted with $7 \mathrm{ml} n$-butyl chloride and rotary mixing for 1 hour at room temperature. 
The organic layer was transferred to a separate tube and washed once with $1 \mathrm{ml}$ water. The solvent layer was then removed and allowed to evaporate to dryness at $50^{\circ} \mathrm{C}$ under a continuous stream of nitrogen. The residue was reconstituted in $50 \mu \mathrm{l}$ methanol for injection ( $1 \mu \mathrm{l})$ into a gas chromatograph/mass spectrometer (Finnigan MAT ITS-40, using a $15 \mathrm{~m} \times 0.25 \mathrm{~mm}$ ID, 0.1 $\mu \mathrm{m}$ film thick DB-1 phenylmethylsilicone FSOT capillary column) operating in full-scan, electron-ionization mode scanning from $\mathrm{m} / \mathrm{z} 45$ to 450 at $1.0 \mathrm{~s} / \mathrm{scan}$. The manifold, injector, and transfer line temperature were held at 220,270 , and $280^{\circ} \mathrm{C}$, respectively. The oven temperature was programmed at $50^{\circ} \mathrm{C}$ for 1 minute, then heated to $230^{\circ} \mathrm{C}$ at $25^{\circ} \mathrm{C} / \mathrm{min}$. After 30 seconds at $230^{\circ} \mathrm{C}$, the temperature was raised to $300^{\circ} \mathrm{C}$ at $5^{\circ} \mathrm{C} / \mathrm{min}$ and maintained for 7 minutes. The carrier gas was helium, and the flow rate was $1 \mathrm{ml} / \mathrm{min}$.

Analyte concentrations were calculated by comparison with matrix-matched standard curves. Peak-area ratios (analyte/istd) were subjected to least squares regression, and the resulting standard curve equation was used to calculate the concentrations of the samples.

\section{Drugs}

Ibogaine $\mathrm{HCl}$ and noribogaine (both from Omnichem, Belgium) were dissolved in distilled water and gently heated by warm running water to ensure better solubility. U50,488 (trans-3,4-dichloro-N-methylN[2-(pyrrolidinyl) cyclohexyl] benzeneacetamide methanesulphonate) donated by Upjohn, Kalamazoo, MI) and dizocilpine (donated by Merck, Sharp and Dohme, Harlow, Essex) were dissolved in distilled water. All drugs were injected 30 minutes before the beginning of the behavioral sessions and 30 minutes before collection of tissue samples in the pharmacokinetic studies.

\section{RESULTS}

\section{Drug Discrimination}

Four doses of noribogaine, three doses of ibogaine and saline were tested in rats $(n=6)$ trained to discriminate ibogaine $(10 \mathrm{mg} / \mathrm{kg})$ from saline. Clear discrimination between the training dose of ibogaine and saline was seen, and there was generalization to noribogaine at doses of 3.2, 10 and $20 \mathrm{mg} / \mathrm{kg}$ as shown in Figure 1 (left section). Analysis of variance for repeated measures revealed a significant effect of dose $(F[7,34]=9.90, p<$ .001). However, while noribogaine produced drug-appropriate responding at $3.2 \mathrm{mg} / \mathrm{kg}$, ibogaine did not yield a similar effect at this dose. Thus the $\mathrm{ED}_{50}$ for noribogaine was $1.98 \mathrm{mg} / \mathrm{kg}$ as compared with $4.51 \mathrm{mg} /$ $\mathrm{kg}$ for ibogaine, indicating the greater potency of noribogaine than ibogaine under these conditions. Drug treatment also affected overall rates of responding
$(\mathrm{F}[7,35]=7.78, p<.001)$ Both ibogaine and noribogaine exhibited a response rate-decreasing effect (Figure 1, left section) but noribogaine was not more potent than ibogaine in this respect.

Generalization to noribogaine was also examined in rats trained to discriminate either U50,488 or dizocilpine from saline. Figure 1 (center sections) shows the clear discriminative response to the training dose of U50,488 and the absence of any similar effect with noribogaine at doses of $1.0,3.2$, or $10 \mathrm{mg} / \mathrm{kg}(n=6)$. The animals trained to discriminate U50,488 showed a low overall rate of responding under both the vehicle and $\mathrm{U} 50,488$ training conditions, and this rate was reduced further by $20 \mathrm{mg} / \mathrm{kg}$ of noribogaine; responding at this dose of noribogaine was suppressed too severely for discriminative effects to be assessed. Figure 1 (right sections) shows that the training dose of dizocilpine produced a clear discriminative response $(n=5)$, that noribogaine engendered only a very small increase in dizocilpine-appropriate responding and had a marked response rate-reducing effect at a dose of $20 \mathrm{mg} / \mathrm{kg}$.

\section{Plasma and Brain Concentrations of Ibogaine and Noribogaine}

As shown in Figure 2 (upper section), plasma concentrations of both ibogaine and noribogaine increased in a manner related to the dose of ibogaine $(F[2,9]=$ $18.5, p<.001)$ and concentrations of noribogaine were slightly greater than those of ibogaine $(F[1,9]=4.43, p=$ $.065)$; for these studies, the ibogaine was administered by intraperitoneal injection 30 minutes before sampling plasma, the same route and timing as in the behavioral experiments described above. The plasma concentrations of noribogaine were even higher when the metabolite itself was injected at the same doses and at the same time $(F[1,18]=37.8, p<.001)$. For example, the plasma concentration of noribogaine was $0.873 \pm 0.054$ $\mu \mathrm{g} / \mathrm{ml}$ after $10 \mathrm{mg} / \mathrm{kg}$ of noribogaine, as compared with $0.366 \pm 0.077 \mu \mathrm{g} / \mathrm{ml}$ after ibogaine $(\mathrm{t}[6]=5.41, p<$ .002). Neither ibogaine nor noribogaine was detectable in plasma from rats receiving saline injections (limit of quantitation $=5 \mathrm{ng} / \mathrm{ml}$ ).

Concentrations of ibogaine and noribogaine in the cerebral cortex increased according to the dose of ibogaine administered systemically $(\mathrm{F}[2,9]=62.6, p<$ .001 ) and again noribogaine was present in slightly larger concentrations than ibogaine $(\mathrm{F}[1,9]=11.8, p<$ $.01)$. Figure 2 (center sections) shows that the concentration of noribogaine in the cortex was much greater after administration of noribogaine than after ibogaine $(F[1,18]=55.9, p<.001)$. For each dose of noribogaine administered systemically, its cortical concentration was greater than that after systemic administration of the same dose of ibogaine. For example, after administration of $10 \mathrm{mg} / \mathrm{kg}$ of noribogaine, its concentration in 


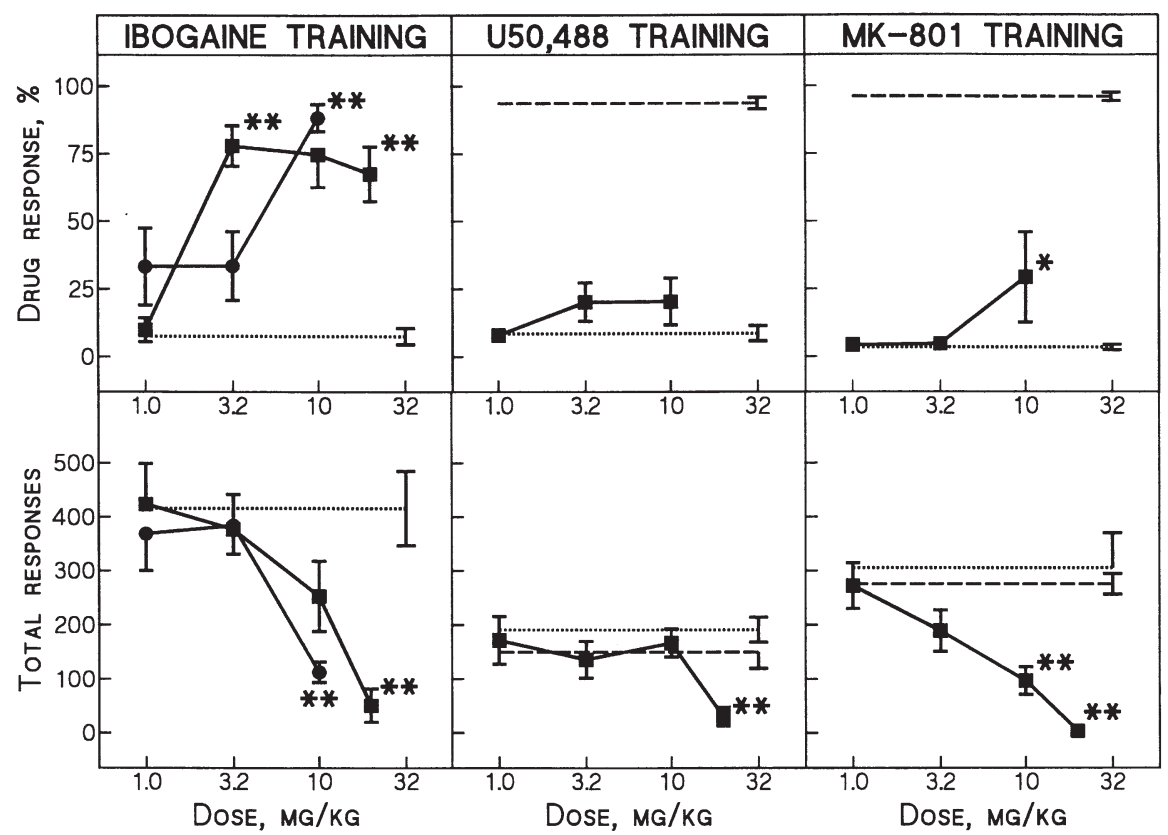

Figure 1. Generalization tests with ibogaine (0) and noribogaine $(\mathbf{\square})$ in three groups of rats trained to discriminate ibogaine $(10 \mathrm{mg} / \mathrm{kg} \mathrm{IP})$, $\mathrm{U} 50,488$ (5 mg/kg SC), or dizocilpine (MK-801, $0.08 \mathrm{mg} / \mathrm{kg}$ IP) from saline $(n=5-6)$. Abscissae, doses of ibogaine or noribogaine administered $30 \mathrm{~min}$ utes prior to 5-minute extinction tests; ordinates, responding on drug-appropriate lever as percentage of total responses (upper panels) and total responses (lower panels). Horizontal dotted lines (.....) show performance after saline; horizontal broken lines (- - - ) show performance after training doses of U50,488 and dizocilpine. ${ }^{* *}=p<.01$, in comparison with saline.) All data shown as means \pm SEM. the cortex was $3.55 \pm 0.22 \mu \mathrm{g} / \mathrm{g}$, as compared with $2.10 \pm$ $0.23 \mu \mathrm{g} / \mathrm{g}$ after administration of ibogaine $(\mathrm{t}[6]=4.56$, $p<.01)$. The concentrations of ibogaine and noribogaine in the striatum were generally very similar for those in the cortex and are not presented in full. As an illustration, after administration of $10 \mathrm{mg} / \mathrm{kg}$ of noribogaine, its concentration in the striatum was $3.22 \pm$ $0.03 \mu \mathrm{g} / \mathrm{g}$, as compared with $1.55 \pm 0.11 \mu \mathrm{g} / \mathrm{g}$ after administration of $10 \mathrm{mg} / \mathrm{kg}$ of ibogaine.

In the cerebellum, noribogaine was detected after administration of either ibogaine or noribogaine, and all concentrations were related to the doses of drugs administered systemically $(\mathrm{F}[2,9]=27.4, p<.001)$. Figure 2 (lower sections) shows that the concentrations of noribogaine in the cerebellum were rather greater after systemic administration of noribogaine than of ibogaine $(\mathrm{F}[1,18]=$ $5.73, p<.05)$, but did not approach the very large concentrations of noribogaine that was seen in the cortex. Results for concentrations in the brainstem were generally similar to those for the cerebellum; for example, after systemic administration of $10 \mathrm{mg} / \mathrm{kg}$ of ibogaine, the brainstem concentrations of ibogaine and noribogaine were $1.90 \pm 0.12 \mu \mathrm{g} / \mathrm{g}$ and $1.09 \pm 0.10 \mu \mathrm{g} / \mathrm{g}$, respectively.

\section{Relationships between Behavioral and Pharmacokinetic Data}

In this section, the relationships between plasma concentrations of ibogaine and noribogaine and their behavioral effects are examined in more detail. As noted above, in rats trained to discriminate ibogaine from saline, noribogaine was at least twice as potent as the parent compound $\left(\mathrm{ED}_{50}\right.$ values of 1.98 and $4.51 \mathrm{mg} / \mathrm{kg}$ for noribogaine and ibogaine, respectively). The pharmaco- kinetic dose-response data were used to estimate (by interpolation) the plasma and brain concentrations of ibogaine and noribogaine at the $\mathrm{ED}_{50}$ doses. This combined pharmacokinetic-behavioral analysis indicated that the $E_{50}$ doses of noribogaine and ibogaine were associated with plasma concentrations of noribogaine of $0.16 \mu \mathrm{g} / \mathrm{ml}$ and $0.19 \mu \mathrm{g} / \mathrm{ml}$, respectively; thus behaviorally equi-effective doses of the two drugs were associated with plasma concentrations of noribogaine that were quite similar. Similarly, the concentrations of noribogaine in the cerebral cortex were estimated as 1.11 and $1.23 \mu \mathrm{g} / \mathrm{g}$, respectively, after administration of the $\mathrm{ED}_{50}$ doses of noribogaine and ibogaine. In contrast, the corresponding estimated cerebellar concentrations of noribogaine after administration of the $\mathrm{ED}_{50}$ doses of noribogaine and ibogaine were 0.34 and $0.62 \mu \mathrm{g} / \mathrm{g}$.

\section{DISCUSSION}

The demonstration of cross-generalization of noribogaine with ibogaine, but not with U50,488 or dizocilpine suggests, first, that the discriminative stimulus effects of ibogaine may be mediated, at least in part, by its metabolite noribogaine; second, any actions that noribogaine may have as a к-opioid agonist or as an uncompetitive NMDA antagonist seem unlikely to play a major role in its discriminative stimulus effects. The study also confirms the status of noribogaine as a biologically active metabolite of ibogaine and correlates, for the first time, the discriminative effects of ibogaine and noribogaine with their concentrations in plasma and brain regions. 


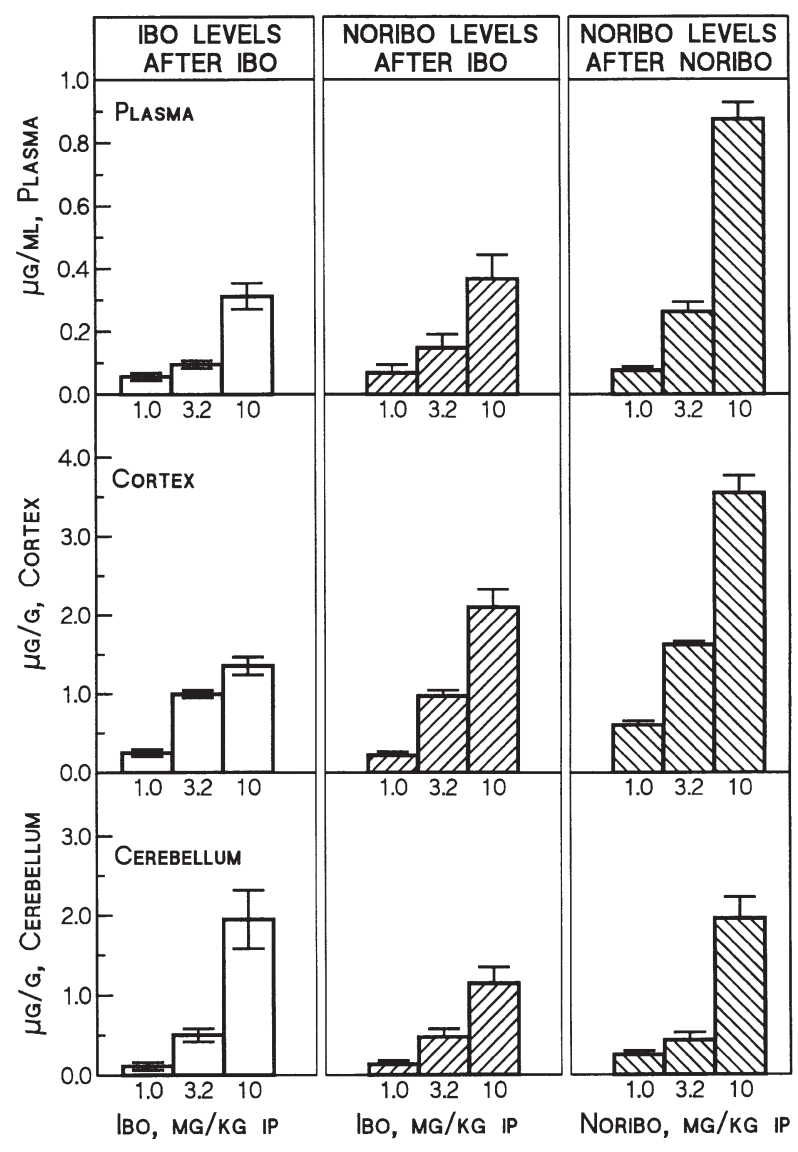

Figure 2. Concentrations of ibogaine (IBO) and noribogaine (NORIBO) in rat plasma, cerebral cortex, and cerebellum 30 minutes after intraperitoneal administration of ibogaine or noribogaine in the doses shown $(n=4)$. All data shown as means \pm SEM.

The drug discrimination results for rats trained on ibogaine are considered first. The generalization from ibogaine to noribogaine supports findings of Helsley et al. (1997) who characterized their results as partial generalization. The discrimination data for noribogaine in the two studies are not greatly different at $71.6 \%$ for 6 $\mathrm{mg} / \mathrm{kg}$ of noribogaine, with slightly lesser generalization at larger doses, in the study of Helsley et al. (1997) and $78.0 \%$ at a $10-\mathrm{mg} / \mathrm{kg}$ dose in the experiment described here. However, the present data bring out more clearly the greater potency of noribogaine than ibogaine in this assay, as reflected in the dose-response data (Figure 1) and the associated $E D_{50}$ values. Resemblances between the effects of ibogaine and noribogaine have also been described on behavioral effects of morphine and cocaine and on extracellular concentrations of dopamine in the nucleus accumbens and striatum (Glick et al. 1996a; Maisonneuve et al. 1997). Noribogaine also appeared to attenuate the development of tolerance to the antinociceptive action of morphine in mice (Bhargava and Cao 1997), suggesting that the metabolite may be mediating the inhibitory effect of ibogaine on morphine tolerance in vivo.

The findings for tissue concentrations of ibogaine and noribogaine confirm and support earlier data that were obtained in Fischer rats (Mash et al. 1995a; Hough et al. 1996; Staley et al. 1996). The present data, obtained with the same pretreatment time as in the behavioral observations, and from hooded rats of the same sex, strain, and age, allow a closer examination of the relationship between tissue concentrations and behavioral effects. From the data presented above, it can be seen that the approximately two-fold greater potency of noribogaine over ibogaine in the discrimination procedure matches its approximately two-fold greater concentration in plasma after administration of equal doses of the two substances. Thus, at the $\mathrm{ED}_{50}$ doses for this behavioral effect, the plasma concentration of noribogaine was similar regardless of whether it was ibogaine or noribogaine that was administered systemically. This suggests that the discriminative stimulus effect of ibogaine $(10 \mathrm{mg} / \mathrm{kg})$ in the present experiments may be attributable largely to the activity of its metabolite noribogaine. Additional experiments are needed to establish the role of noribogaine more definitively, including tests in which the metabolic conversion to noribogaine is blocked and different training doses of ibogaine are used.

The results for concentrations of noribogaine in the higher regions of the brain (cortex and striatum) were very similar to those for plasma; at the $\mathrm{ED}_{50}$ doses for the discriminative effect, the concentrations of noribogaine in these tissues were similar regardless of ibogaine or noribogaine was administered systemically. In contrast, concentrations of noribogaine in lower brain regions (cerebellum and brainstem) after administration of noribogaine were little more than half of those after ibogaine. Assuming, as argued above, that the discriminative effect of ibogaine may be mediated to a large extent by the action of its metabolite noribogaine, the most parsimonious explanation for these data on brain distributions is that the site of action of noribogaine resides primarily in the higher regions of the brain. Strong ibogaine-induction of the early/immediate gene product c-fos in cortex, hippocampus, and paraventricular hypothalamus has indicated previously that these areas are possible substrates for the psychopharmacological properties of ibogaine (Scallet et al. 1996). More extensive pharmacokinetic data as well as additional studies to localize the site of action of ibogaine (for example, studies involving microinfusions into brain regions) are needed to test these hypotheses further. The relatively lower concentration of noribogaine in the cerebellum may be related to its five-fold lower potency as a tremorigenic agent (Zetler et al. 1972). The ibogaine congener 18-methoxycoronaridone has also been reported to have less tremorigenic effect 
than ibogaine while retaining other biological activity (Glick et al. 1996b). The relatively low concentration of noribogaine in the cerebellum suggests that congeners of ibogaine may have a therapeutic index more favorable than that of ibogaine itself.

The present tests for $\kappa$-opioid agonist-like and NMDA antagonist-like behavioral effects of noribogaine were negative. Previous studies have suggested some similarity between the discriminative effects of dizocilpine and very large doses of ibogaine in mice (Popik et al. 1995), but in the present studies it was not possible to extend such observations to noribogaine in the rat. Tests for generalization from dizocilpine to ibogaine were also negative (Helsley et al. 1998b; Jones et al. 1998; Zubaran and Stolerman, unpublished data), so the discrepancy may be related to the different species or behavioral procedures; Popik et al. (1995) carried out their experiments using a T-maze procedure in mice, so there were major methodological differences from the present studies and from those of Helsley et al. (1998b) using rats trained in operant chambers. Studies in rats trained with doses of dizocilpine and U50,488 that differ from those used in the present experiments may also yield different results. Nevertheless, our negative results of generalization tests with noribogaine in rats trained with the $\kappa$-opioid agonist U50,488 mirror those of earlier studies in which rats trained to discriminate ibogaine failed to generalize to U50,488 (Helsley et al. 1998b). Therefore, it would seem that any к-opioid agonist-like and NMDA antagonist-like effects of noribogaine do not contribute in a very significant manner to its discriminative stimulus properties.

In summary, the present study suggests that noribogaine may be the major entity that produces the discriminative effect of ibogaine. Furthermore, the lack of generalization from either dizocilpine or U50,488 to noribogaine suggests that neither an antagonist action at NMDA receptors nor a $\kappa$-opioid agonist-like effect mediates the noribogaine stimulus.

\section{ACKNOWLEDGMENTS}

This research was supported by grants from CAPES (Brazil), the National Institute on Drug Abuse (DA 05543) and the Addiction Research Fund. We thank Sherelle Chamberlain for assistance with training some of the rats.

\section{REFERENCES}

Bhargava HN, Cao Y-J (1997): Effects of noribogaine on the development of tolerance to antinociceptive action of morphine in mice. Brain Res 771:343-346

Cappendijk SLT, Dzoljic MR (1993): Inhibitory effects of ibogaine on cocaine self-administration in rats. Eur J Pharmacol 241:261-265
Chamberlain SS, Stolerman IP (1997): Dissecting the cyclazocine stimulus in rats. J Psychopharmac 11(Suppl):A13

Deecher DC, Teitler M, Soderlund DM, Bornmann WG, Kuehne ME, Glick SD (1992): Mechanisms of action of ibogaine and harmaline congeners based on radioligand binding studies. Brain Res 571:242-247

Glick SD, Pearl SM, Cai J, Maisonneuve IM (1996a): Ibogaine-like effects of noribogaine in rats. Brain Res 713:294-297

Glick SD, Kuehne ME, Maisonneuve IM, Bandarage UK, Molinari HH (1996b): 18-methoxycoronaridine, a nontoxic iboga alkaloid congener: Effect on morphine and cocaine self-administration and on mesolimbic dopamine release in rats. Brain Res 719:29-35

Hearn WL, Pablo J, Hime GW, Mash, DC (1995): Identification and quantitation of ibogaine and an o-demethylated metabolite in brain and biological fluids using gas chromatography-mass spectrometry. J Anal Toxicol 19:427-434

Helsley S, Rabin RA, Winter JC (1997): The effects of noribogaine and harmaline in rats trained with ibogaine as a discriminative stimulus. Life Sci 60:147-153

Helsley S, Fiorella D, Rabin RA, Winter JC (1998a): Behavioral and biochemical evidence for a nonessential $5-\mathrm{HT}_{2 \mathrm{~A}}$ component of the ibogaine-induced discriminative stimulus. Pharmacol Biochem Behav 59:419-425

Helsley S, Filipink RA, Bowen WD, Rabin RA, Winter JC (1998b): The effects of sigma, PCP, and opiate receptors ligands in rats trained with ibogaine as a discriminative stimulus. Pharmacol Biochem Behav 59:495-503

Hough LB, Pearl SM, Glick SD (1996): Tissue distribution of ibogaine after intraperitoneal and subcutaneous administration. Life Sci 58:119-122

Jones HE, Li H, Balster RL (1998): Failure of ibogaine to produce phencyclidine-like discriminative stimulus effects in rats and monkeys. Pharmacol Biochem Behav 59:413418

Ley FR, Jeffcoat AR, Thomas BF (1996): Determination of ibogaine in plasma by gas chromatography-chemical ionization mass spectrometry. J Chromatogr A723:101-109

Lotsof HS (1985): Rapid method for interrupting the narcotic addiction syndrome. US Patent 4,499,096

Lotsof HS (1992): Rapid method for interrupting or attenuating poly-drug dependency syndromes. US Patent 5,152,994

Maisonneuve IM, Keller RW Jr, Glick SD (1991): Interactions between ibogaine, a potential anti-addictive agent, and morphine: An in vivo microdialysis study. Eur J Pharmacol 199:35-42

Maisonneuve IM, Visker KE, Mann GL, Bandarage UK, Kuehne ME, Glick SD (1997): Time-dependent interactions between iboga agents and cocaine. Eur J Pharmacol 336:123-126

Mash DC, Staley JK, Baumann MH, Rothman RB, Hearn WL (1995a): Identification of a primary metabolite of ibogaine that targets serotonin transporters and elevates serotonin. Life Sci 57:45-50

Mash DC, Staley JK, Pablo JP, Holohean AM, Hackman JC, Davidoff RA (1995b): Properties of ibogaine and its principal metabolite (12-hydroxyibogamine) at the MK801 binding site of the NMDA receptor complex. Neurosci Lett 192:53-56 
Palumbo PA, Winter JC (1992): Stimulus effects of ibogaine in rats trained with yohimbine, DOM, or LSD. Pharmacol Biochem Behav 43:1221-1226

Pearl S, Herrick-Davis K, Teitler M, Glick SD (1995): Radioligand-binding study of noribogaine, a likely metabolite of ibogaine. Brain Res 675:342-344

Popik P, Layer RT, Skolnick P (1994): The putative antiaddictive drug ibogaine is a competitive inhibitor of $\left[{ }^{3} \mathrm{H}\right] \mathrm{MK}-801$ binding to the NMDA receptor complex. Psychopharmacology 114:672-674

Popik P, Layer RT, Fossom LH, Benveniste M, Geter-Douglass B, Witkin JM, Skolnick P (1995): NMDA antagonist properties of the putative antiaddictive drug, ibogaine. J Pharmacol Exp Ther 275:753-760

Pratt JA, Stolerman IP, Garcha HS, Giardini V, Feyerabend C (1983): Discriminative stimulus properties of nicotine: Further evidence for mediation at a cholinergic receptor. Psychopharmacology 81:54-60

Sanger DJ, Zivkovic B (1989): The discriminative stimulus effects of MK-801: Generalisation to other N-methyl-D-aspartate receptor antagonists. J Psychopharmacol 3:198-204

Scallet AC, Ye X, Ali SF (1996): NOS and fos in rat and mouse brain regions. Possible relation to ibogaineinduced Purkinje cell loss. Ann N Y Acad Sci 801:227238

Schechter MD (1997): Serotonergic mediation of fenfluramine discriminative stimuli in Fawn-Hooded rats. Life Sci 60:83-90

Schechter MD, Gordon TL (1993): Comparison of the behav- ioural effects of ibogaine from three sources: Mediation of discriminative activity. Eur J Pharmacol 249:79-84

Sheppard SG (1994): A preliminary investigation of ibogaine: Case reports and recommendations for further study. J Subst Abuse Treat 11:379-385

Staley JK, Ouyang Q, Pablo J, Hearn WL, Flynn DD, Rothman RB, Rice KC, Mash DC (1996): Pharmacological screen for activities of 12-hydroxyibogamine: A primary metabolite of the indole alkaloid ibogaine. Psychopharmacology 127:10-18

Stolerman IP, Garcha HS, Pratt JA, Kumar R (1984): Role of training dose in discrimination of nicotine and related compounds by rats. Psychopharmacology 84:413-419

Sweetnam PM, Lancaster J, Snowman A, Collins JL, Perschke S, Bauer C, Ferkany J (1995): Receptor binding profile suggests multiple mechanisms of action are responsible for ibogaine's putative anti-addictive activity. Psychopharmacology 118:369-376

Winer BJ (1970): Statistical Principles in Experimental Design. New York, McGraw-Hill

Witkin JM, Brave S, French D, Geter-Douglass B (1995): Discriminative stimulus effects of R-(+)-3-amino-1-hydroxypyrrolid-2-one, [(+)-HA-966], a partial agonist of the strychnine-insensitive modulatory site of the N-methylD-aspartate receptor. J Pharmacol Exp Ther 275:12671273

Zetler G, Singbartl G, Schlosser L (1972): Cerebral pharmacokinetics of tremor-producing harmala and iboga alkaloids. Pharmacology 7:237-248 